\title{
A Bilateral Lumbar Multidermatomal Herpes Zoster in an Elderly Woman with Chronic Kidney Disease
}

Filomena Puntillo (D) - Mariateresa Giglio - Angela Preziosa •

Roberta Mele $\cdot$ Nicola Brienza

Received: May 19, 2020 / Published online: June 8, 2020

(C) The Author(s) 2020

\section{ABSTRACT}

Herpes zoster (HZ) is a painful rash caused by the reactivation of the varicella-zoster virus (VZV) permanently latent within the cranial or dorsal root ganglia. Usually the rash presents in only one side of the body, in a single dermatome or restricted to a part of it. In immunocompromised patients, more than one contiguous unilateral dermatome, called multidermatomal HZ, has been described, usually in cervical dermatomes. Bilateral rash is rare. Besides immunosuppression, the major risk factors for virus reactivation are older age and female gender. This is a case of a bilateral lumbar multidermatomal HZ in an elderly woman with chronic renal failure.

Digital Features To view digital features for this article go to https://doi.org/10.6084/m9.figshare.12387530.

F. Puntillo $(\bowtie)$

Department of Interdisciplinary Medicine,

University of Bari "Aldo Moro", Bari, Italy

e-mail: filomena.puntillo@uniba.it;

nuccia.puntillo@gmail.com

M. Giglio · A. Preziosa - R. Mele

Anesthesia, Intensive Care and Pain Unit,

Policlinico Hospital, Bari, Italy

N. Brienza

Department of Emergency and Organ

Transplantation, University of Bari "Aldo Moro",

Bari, Italy
Keywords: Bilateral; Herpes zoster; Kidney disease; Lumbar; Multidermatomal

\section{Key Summary Points}

Herpes zoster (HZ) is a painful rash caused by the reactivation of the varicella-zoster virus (VZV).

Older age, female gender, and immunosuppression are the major risk factors for virus reactivation.

Usually the rash is unilateral and is restricted to a single dermatome or to a part of it.

Bilateral rash is rare and multidermatomal $\mathrm{HZ}$ is more frequent in cervical dermatomes.

This is a case of a bilateral lumbar multidermatomal HZ in an elderly woman with chronic renal failure.

\section{CASE}

Herpes zoster (HZ) is a painful rash caused by the reactivation of the varicella-zoster virus (VZV) permanently latent within the cranial or dorsal root ganglia after a primary childhood 


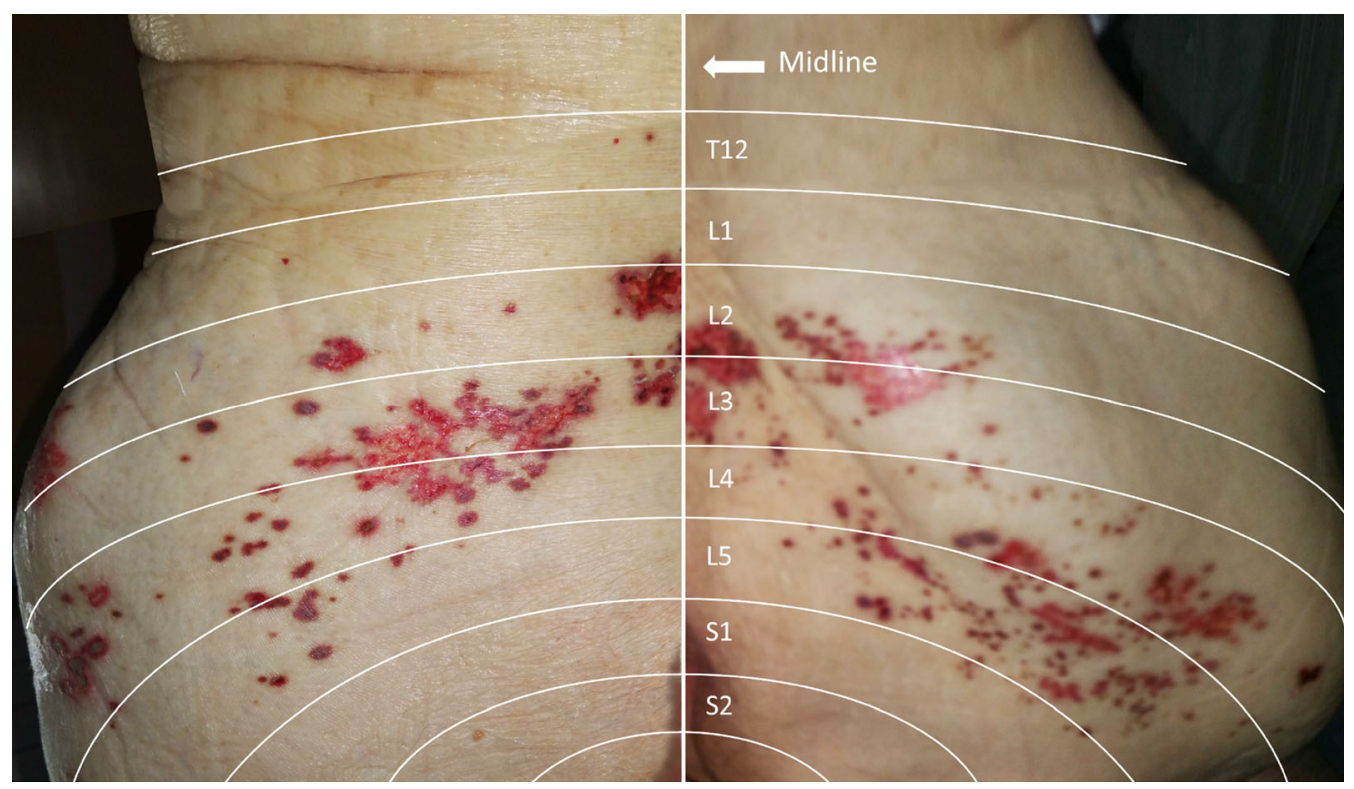

Fig. 1 Bilateral multidermatomal $\mathrm{HZ}$ rash in the lumbar dermatomes. The rash is in the phase of the formation of the crusts and dermatomal distribution is quite similar in the two sides

infection. Also known as shingles, it presents as a vesicular rash that usually affects only one side of the body, distributed in a single dermatome or restricted to a part of it [1]. In immunocompromised patients, more than one contiguous unilateral dermatome, called multidermatomal HZ, has been described, usually in cervical dermatomes [2]. Although it is unclear if VZV spreads across adjacent ganglia or to neighboring peripheral nerves, two hypothesis have been proposed to justify multidermatomal $\mathrm{HZ}$ propensity for cervical region: the rich innervation of cervical dermatomes covering the head and neck [3] and the shorter length of the sensory nerves of cranial and cervical dermatomes compared to thoracic or lumbar ones [2]. Bilateral non-contiguous herpes zoster, also termed herpes zoster duplex, has been reported in immunocompromised patients [4], and in a patient with end-stage renal failure [5]. Finally, one case of thoracic HZ duplex, bilateralis, and symmetricus in an immunocompetent subject has been published [6].

Besides immunosuppression, the major risk factors for virus reactivation are older age and female gender [7]. Prodromal itching, numbness, or burning sensations precede the maculopapular rash, which quickly becomes very painful. The eruption evolves to pustulation followed by ulceration and crusting [8]. Early antiviral therapy is the primary treatment of $\mathrm{HZ}$, but pain management is always needed during the progression of disease until healing, usually within a month. Post-herpetic neuralgia (PHN) is the main complication of $\mathrm{HZ}$ occurring in $8-33 \%$ of affected patients. Once again, PHN frequency and severity increase with age [9] and may last for months or even years. Due to its poor response to analgesics, PHN can cause sleeping problems, anorexia, weight loss, and depression, compromising self-care and social life [10]. In order to avoid $\mathrm{HZ}$ and PHN, prophylactic vaccination has been strongly recommended in older adults [11].

This is the case of a bilateral lumbar multidermatomal HZ eruption in a 91-year-old woman with chronic kidney disease. The rash simultaneously involved bilateral dermatomes from L2 to L5 (Fig. 1). The patient complained of severe back pain, weakness in the lower limbs, and walking impairment so that her quality of life and functional status were very compromised. The patient was admitted to the hospital. Antiviral therapy was started and a pain medicine consultation was requested. Antidepressants and anticonvulsants were 
prescribed at low doses according to renal function, with gradual and progressive improvement of symptoms. The patient was discharged home 2 weeks later. Other than older age and kidney disease, no other risk factors were revealed.

\section{ACKNOWLEDGEMENTS}

We thank the participants of the study

Funding. No funding or sponsorship was received for this study or publication of this article.

Authorship. All named authors meet the International Committee of Medical Journal Editors (ICMJE) criteria for authorship for this article, take responsibility for the integrity of the work as a whole, and have given their approval for this version to be published.

Disclosures. Filomena Puntillo is a member of the journal's Editorial Board. Mariateresa Giglio, Angela Preziosa, Roberta Mele, and Nicola Brienza, have nothing to disclose.

Compliance with Ethics Guidelines. Informed consent for publication was obtained from the patient.

Open Access. This article is licensed under a Creative Commons Attribution-NonCommercial 4.0 International License, which permits any non-commercial use, sharing, adaptation, distribution and reproduction in any medium or format, as long as you give appropriate credit to the original author(s) and the source, provide a link to the Creative Commons licence, and indicate if changes were made. The images or other third party material in this article are included in the article's Creative Commons licence, unless indicated otherwise in a credit line to the material. If material is not included in the article's Creative Commons licence and your intended use is not permitted by statutory regulation or exceeds the permitted use, you will need to obtain permission directly from the copyright holder. To view a copy of this licence, visit http:// creativecommons.org/licenses/by-nc/4.0/.

\section{REFERENCES}

1. Cohen JI. Clinical practice: herpes zoster. N Engl J Med. 2013;369(3):255-63.

2. Beuerlein KG, Strowd LC. Multidermatomal herpes zoster: a pain in the neck? Dermatol Online J. 2019;25(11):1-4.

3. Besné I, Descombes C, Breton L. Effect of age and anatomical site on density of sensory innervation in human epidermis. Arch Dermatol. 2002;138: 1445-1450.

4. Peretz A, Nowatzky J, Steiner I. Herpes zoster duplex bilateralis. BMJ Case Rep. 2009. https://doi.org/10. 1136/bcr.2006.114116.

5. Akimoto T, Muto S, Nagata D. Bilateral herpes zoster in a patient with end-stage kidney disease. Int Med Case Rep J. 2017;19(10):209-12.

6. Agrawal S, Aara N, Bumb R. Herpes zoster duplex bilateralis symmetricus in an immunocompetent subject. Int J Dermatol. 2014;53(4):e281-e282282.

7. Opstelten W, Van Essen GA, Schellevis F, Verheij TJM, Moons KGM. Gender as an independent risk factor for herpes zoster: a population-based prospective study. Ann Epidemiol. 2006;16(9): 692-5.

8. Gnann JW Jr, Whitley RJ. Clinical practice. Herpes zoster. N Engl J Med. 2002;1(5):340-6.

9. Curran D, Oostvogels L, Heineman T, et al. Quality of life impact of an adjuvanted recombinant zoster vaccine in adults aged 50 years and older. J Gerontol A Biol Sci Med Sci. 2019;74(8):1231-8.

10. Schmader KE, Sloane R, Pieper C, Coplan PM, Nikas A, Saddier P, Chan IS, Choo P, Levin MJ, Johnson G, et al. The impact of acute herpes zoster pain and discomfort on functional status and quality of life in older adults. Clin J Pain. 2007;23:490-6.

11. Szucs TD, Pfeil AM. A systematic review of the cost effectiveness of herpes zoster vaccination. Pharmacoeconomics. 2013;31:125-36. 